ARTICLE

\title{
Active methanogenesis during the melting of Marinoan snowball Earth
}

\author{
Zhouqiao Zhao (1) ${ }^{1,7}$, Bing Shen ${ }^{1 凶}$, Jian-Ming Zhu (i) ${ }^{2 凶}$, Xianguo Lang ${ }^{3 凶}{ }^{\circledR}$, Guangliang Wu ${ }^{2}$, Decan Tan ${ }^{4,5}$, \\ Haoxiang Pei ${ }^{6}$, Tianzheng Huang ${ }^{1}$, Meng Ning ${ }^{1} \&$ Haoran Ma (iD ${ }^{1}$
}

Geological evidence indicates that the deglaciation of Marinoan snowball Earth ice age ( $635 \mathrm{Myr}$ ago) was associated with intense continental weathering, recovery of primary productivity, transient marine euxinia, and potentially extensive $\mathrm{CH}_{4}$ emission. It is proposed that the deglacial $\mathrm{CH}_{4}$ emissions may have provided positive feedbacks for ice melting and global warming. However, the origin of $\mathrm{CH}_{4}$ remains unclear. Here we report $\mathrm{Ni}$ isotopes $\left(\delta^{60} \mathrm{Ni}\right)$ and Yttrium-rare earth element (YREE) compositions of syndepositional pyrites from the upper most Nantuo Formation (equivalent deposits of the Marinoan glaciation), South China. The Nantuo pyrite displays anti-correlations between $\mathrm{Ni}$ concentration and $\delta^{60} \mathrm{Ni}$, and between $\mathrm{Ni}$ concentration and $\mathrm{Sm} / \mathrm{Yb}$ ratio, suggesting mixing between $\mathrm{Ni}$ in seawater and $\mathrm{Ni}$ from methanogens. Our study indicates active methanogenesis during the termination of Marinoan snowball Earth. This suggests that methanogenesis was fueled by methyl sulfides produced in sulfidic seawater during the deglacial recovery of marine primary productivity.

\footnotetext{
${ }^{1}$ Key Laboratory of Orogenic Belts and Crustal Evolution, MOE, School of Earth and Space Science, Peking University, Beijing, China. ${ }^{2}$ State Key Laboratory of Geological Processes and Mineral Resources, Institute of Earth Sciences, China University of Geosciences, Beijing, China. ${ }^{3}$ State Key Laboratory of Oil and Gas Reservoir Geology and Exploitation \& Institute of Sedimentary Geology, Chengdu University of Technology, Chengdu, China. ${ }^{4}$ State Key Laboratory of Environmental Geochemistry, Institute of Geochemistry, Chinese Academy of Sciences, Guiyang, China. ${ }^{5}$ University of Chinese Academy of Sciences, Beijing, China. ${ }^{6}$ Institute of Mineral Resource, Chinese Academy of Geological Sciences, Beijing, China. ${ }^{7}$ Present address: Department of Atmospheric and

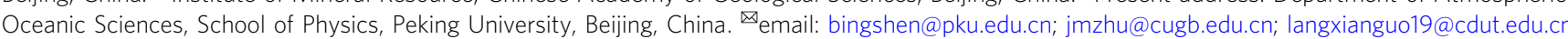


T he Marinoan snowball Earth glaciation ( 650-635 Myr ago) represents one of the most severe ice ages in Earth's history, during which ice sheets may have reached tropical latitudes and the Earth may have remained frozen for millions of years ${ }^{1}$. Geological, geochemical, and paleontological data indicate that the termination of the Marinoan glaciation was immediately followed by atmosphere and ocean oxygenation, as well as the diversification of eukaryotes in the earliest Ediacaran Period ${ }^{2-4}$. The coincidence of these major events suggests that there was possible causal linkage among global glaciation, environmental change, and biological evolution. To understand the consequences of the Marinoan snowball Earth, it is essential to reconstruct the sequence of events that occurred during deglaciation.

The deglaciation of Marinoan snowball Earth was associated with intense continental weathering, recovery of marine productivity, development of oceanic euxinia, and global precipitation of cap carbonate ${ }^{5-7}$. The snowball Earth hypothesis suggests that high atmospheric $\mathrm{CO}_{2}$ level was accumulated during the snowball Earth. The $\mathrm{CO}_{2}$ accumulation generated a supergreenhouse condition that resulted in the rapid meltdown of ice on the Earth's surface ${ }^{8}$. Such a high atmospheric $\mathrm{CO}_{2}$ level would trigger intense continental weathering, resulting in the global precipitation of cap carbonate ${ }^{9}$. Substantial continental weathering is supported by a positive excursion in $\mathrm{Mg}$ isotopes (e.g., $\delta^{26} \mathrm{Mg}$ anomaly found in the siltstone between glacial debris and the cap carbonate ${ }^{5}$ ). Nitrogen isotopes suggest active biogeochemical cycle during the glacial episodes ${ }^{10}$. Because chemical weathering could transport abundant nutrients and a surge of sulfate into the ocean, it is inferred that the deglaciation includes an increase in organic matter production and microbial sulfate reduction (MSR) in seawater ${ }^{7}$. High primary productivity and marine euxinia are evidenced by the abundant deposition of syndepositional pyrite in the topmost of Nantuo Formation throughout the Yangtze Block, South China. These pyrites show relatively high sulfur isotope values $\left(\delta^{34} S_{\text {py }}\right)$ and a nonzero multiple sulfur isotope compositions $\left(\Delta^{33} S\right)$. Sulfur isotopic modeling suggests that high $\delta^{34} S_{\mathrm{py}}$ values and high pyrite content result from active MSR in seawater, generating an episode of oceanic euxinia prior to cap carbonate precipitation ${ }^{7}$.

Another event that might occur during deglaciation is massive $\mathrm{CH}_{4}$ emission. It has been proposed that destabilization of $\mathrm{CH}_{4}$ clathrates may have provided positive feedbacks for the termination of Marinoan snowball Earth ice age and dramatic climate changes ${ }^{11,12}$. Geological evidence of deglacial $\mathrm{CH}_{4}$ emission includes sporadic occurrences of extremely low $(<-40 \%)$ carbonate carbon isotopes $\left(\delta^{13} \mathrm{C}_{\text {carb }}\right)$ in some cap carbonate ${ }^{13}$. while some cap carbonate fabrics, such as tepee-like structures, resemble structures in cold $\mathrm{CH}_{4}$ seeps ${ }^{11,13}$.

However, it remains unclear what the source of $\mathrm{CH}_{4}$ may have been, and how $\mathrm{CH}_{4}$ emission is linked with marine biogeochemical cycles during deglaciation. $\mathrm{CH}_{4}$ clathrate formation requires an ample supply of organic matter. Here, we suggest that the deglacial recovery of primary productivity would favor methanogenesis and $\mathrm{CH}_{4}$ accumulation in clathrate. In this study, we tested this hypothesis by using nickel $(\mathrm{Ni})$ isotopes and yttrium-rare earth elements (YREE) compositions. We analyzed $\mathrm{Ni}$ isotopes and YREE compositions of syndepositional pyrite in the deglacial deposits from the Nantuo Formation, South China. The geochemical data indicate active methanogenesis during the melting of Marinoan snowball Earth and provides important perspectives on the termination of Marinoan snowball Earth ice age.

\section{Results}

Geological setting and the Nantuo pyrite concretions. The Cryogenian deposits in the Yangtze Block are composed of, in ascending order, the Chang'an, Fulu, Datangpo, and Nantuo Formations. The Nantuo Formation (ca. 650-635 Ma) is correlated with the glacial deposition of the Marinoan global glaciation $^{14,15}$. The Nantuo Formation is conformably overlain by a 3-6 $m$ thick cap carbonate in the basal Doushantuo Formation. In the Yangtze Block, the Nantuo Formation attenuates from $2000 \mathrm{~m}$ of basin facies in the southeast (present orientation) to a few meters of shelf facies in the northwest (Fig. 1). Non-glacial

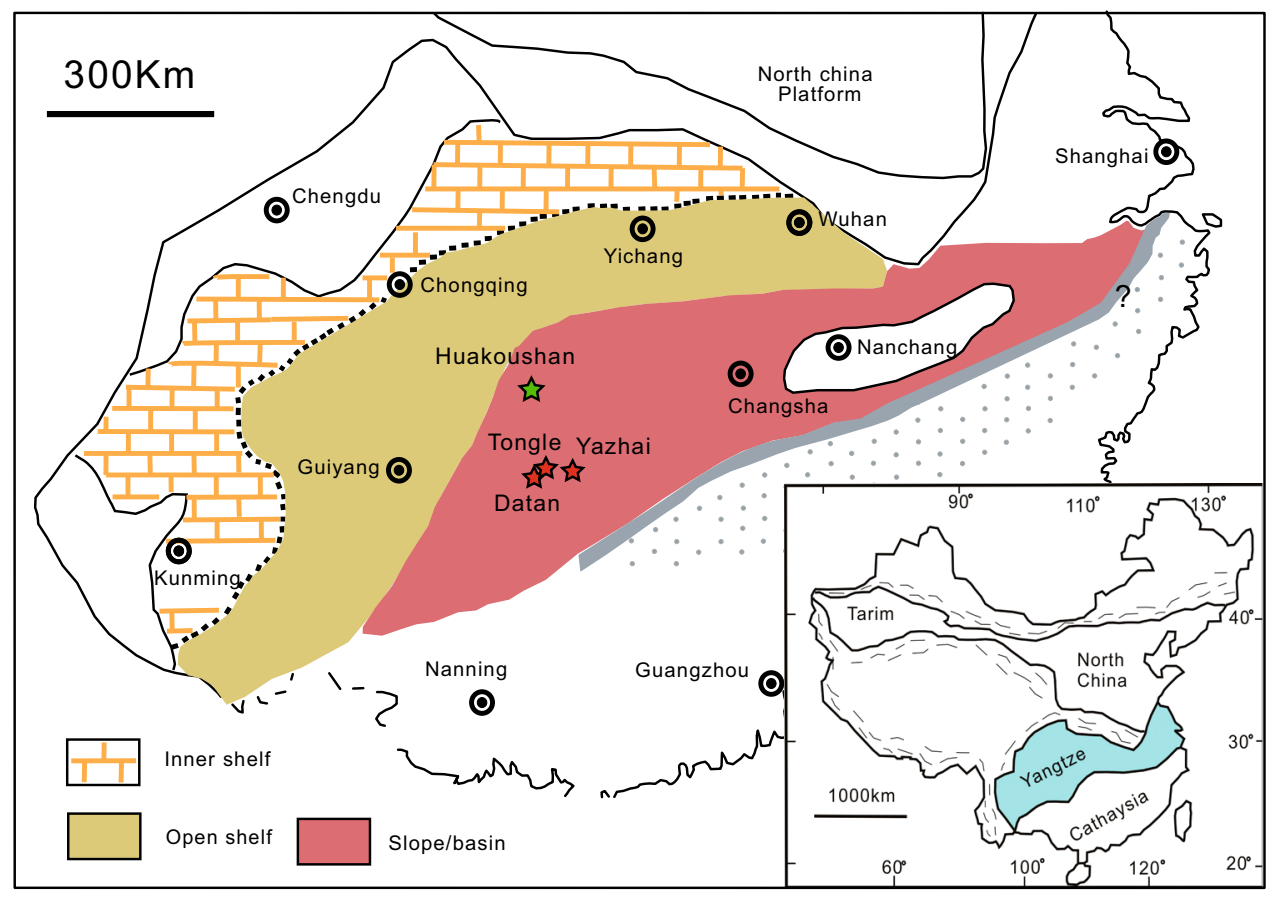

Fig. 1 The paleogeographic map of South China Block in late Neoproterozoic Era7. The green star marks the location of Huakoushan section (slope environment). The red stars mark the locations of Yazhai, Tongle, and Datan sections (basin environment). 


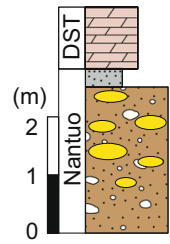

Slope
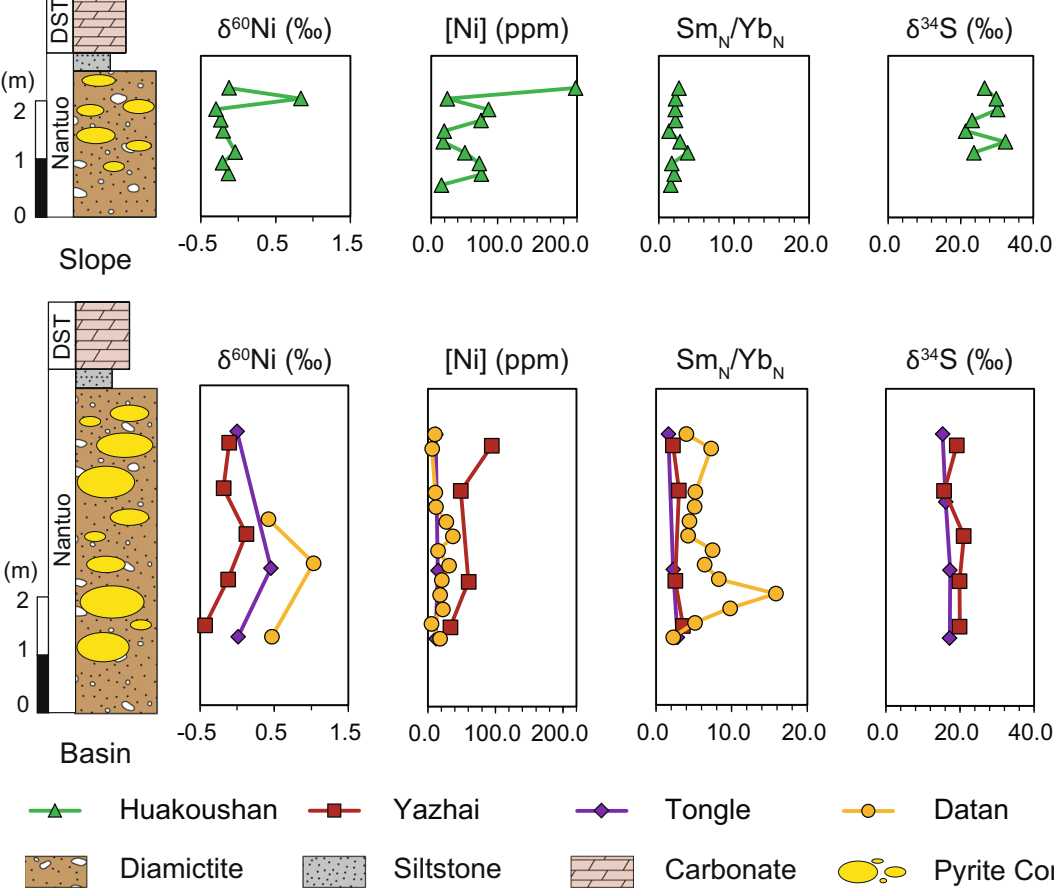

Yazhai

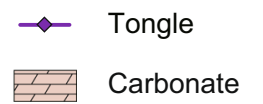

- Datan

Siltstone

Carbonate

Fig. 2 The stratigraphic profiles of geochemical data. Stratigraphic variations of $\delta^{60} \mathrm{Ni}$, Ni concentration, Sm/Yb (normalized by post-Archean Australian shale, PAAS), and $\delta^{34} S$ of pyrite concretions in the upper Nantuo Formation. The $\delta^{34} S$ values are from Lang et. al. ${ }^{7}$. DST here refers to Doushantuo Formation.

marine and distal glaciomarine facies associations are identified in the upper part of the Nantuo Formation throughout the Yangtze Block, suggesting that the deglaciation had occurred before the cap carbonate precipitation ${ }^{16}$. Abundant pyrite concretions are discovered in the top $0.5-10 \mathrm{~m}$ of the Nantuo Formation (Fig. 2) ${ }^{7}$. Their abundance and size decrease from the basin to shelf sections ${ }^{7}$.

In this study, pyrite concretions from four sections were analyzed, including one slope (Huakoushan) and three basin sections (Tongle, Yazhai, and Datan; Fig. 1). Pyrite concretions occur as elliptical nodules with their long axis parallel to the bedding surface (Fig. S2 in SI). The diameter of pyrite concretions can be as large as $20 \mathrm{~cm}$ in basin sections, but is reduced to $\sim 1 \mathrm{~cm}$ in shelf regions. Pyrite nodules are composed of densely packed euhedral pyrite crystals, no framboidal pyrite, or framboidal cores are identified ${ }^{7}$.

$\mathrm{Ni}$ isotopes and YREE data. $\delta^{60} \mathrm{Ni}$ values of the Nantuo pyrites range from -0.5 to $+1.0 \%$ (Fig. 2 and Table S1 in SI). There is an anticorrelation between $\delta^{60} \mathrm{Ni}$ and $\mathrm{Ni}$ concentration, i.e., samples with high $\delta^{60} \mathrm{Ni}$ values are characterized by low $\mathrm{Ni}$ concentrations (Fig. 3a). The YREE pattern for pyrite (normalized to post-Archean Australian shale, PAAS) is facies dependent (Fig. 4 and Table S2 in SI). Pyrites from the basin sections are strongly depleted in heavy REE (HREE), showing light REE $(\mathrm{LREE}) \approx \mathrm{MREE}>\mathrm{HREE}$ pattern, while those from the slope section enrich in middle REE (MREE). All pyrite samples show a slight Eu negative anomaly, but no yttrium anomaly. There is an inverse correlation between $\mathrm{Ni}$ concentration and MREE/HREE (Fig. 3b), but Ni concentration and MREE/LREE do not show any correlation (Fig. S1).

\section{Discussion}

Pyrite could be formed by the following processes: direct precipitation from seawater, post-depositional precipitation in hydrothermal activity, or in situ (authigenic) precipitation in porewater during early diagenesis. Direct precipitation from seawater could be ruled out since the Nantuo pyrite consists of euhedral crystals, and no framboidal pyrite or framboidal core within pyrite were found (Fig. S3 in SI) ${ }^{7}$. The hydrothermal origin is also unlikely since the REE patterns of Nantuo pyrites contrast with that of hydrothermal pyrite, which is commonly characterized by a positive $\mathrm{Eu}$ anomaly with a flat REE distribution pattern ${ }^{17-19}$.

Petrological evidence indicates that the Nantuo pyrite concretions were precipitated within sediment porewater ${ }^{7}$. The euhedral pyrite crystal in glacial diamictite suggests an authigenic origin of the pyrite (Fig. S3 in SI) ${ }^{7}$. Meanwhile, the tightly packed pyrite crystals are either cemented by silica or wrapped by siliciclastic matrix (Fig. S3 in SI), suggesting the pyrite formation predating sediment compaction. Thus, pyrite samples analyzed in this study are mainly formed during early diagenesis, recording the geochemical signal of porewater.

The authigenic pyrite formation in porewater requires $\mathrm{Fe}$ supply in sediment. Theoretically iron oxides are thermodynamically unstable and pyrite precipitation is spontaneous in sulfidic water. However, no framboidal structure or framboidal core is found in Nantuo pyrite, which is in contrast with the direct precipitation from sulfidic seawater. Here, we suggest that reactive $\mathrm{Fe}$ is supplied by microbial iron reduction (MIR) of ferrihydrites in sediment. Recent studies indicate active MIR in porewater with the water column remaining sulfidic ${ }^{20,21}$, confirming transportation of particulate iron oxides through sulfidic water column. The absence of depositional pyrite formation in sulfidic water column may result from kinetic prohibition of pyritization of particulate iron oxides ${ }^{21}$.

In addition, high $\delta^{34} \mathrm{~S}$ values up to $+40 \%$ of the Nantuo pyrite (Fig. 2) indicate that MSR mainly occurred in the water column with seawater pervasively sulfidic $\left(\mathrm{H}_{2} \mathrm{~S}\right.$-enriched), and the Nantuo pyrites were mainly formed in sediment porewater ${ }^{7}$. High $\delta^{34} S$ values could be explained by either MSR in closed porewater 

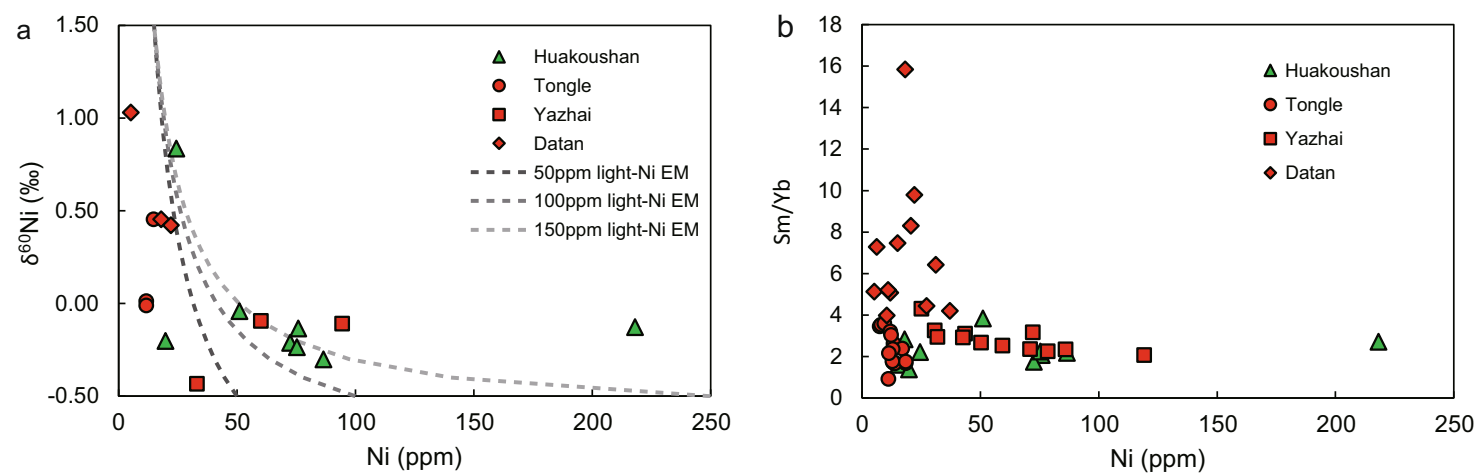

Fig. 3 The relationships between $\mathrm{Ni}$ concentration, $\mathrm{Ni}$ isotopes, and rare earth element pattern of the Nantuo pyrite samples. a Cross-plot of $\mathrm{Ni}$ concentration versus $\delta^{60} \mathrm{Ni}$. There is an anticorrelation between $\mathrm{Ni}$ concentrations and $\delta^{60} \mathrm{Ni}$ values. Dash lines represent the relationship between $\mathrm{Ni}$ concentration and isotopes in a theoretical mixing model. Here, $\delta^{60} \mathrm{Ni}$ values of the two end-members are $-0.5 \%$ and $+1.5 \%$, respectively. The $\mathrm{Ni}$ concentration of the high- $\delta^{60} \mathrm{Ni}$ end-member is fixed to 20 p.p.m., while that of low- $\delta^{60} \mathrm{Ni}$ end-member is assigned to 50,100 , and 250 p.p.m., respectively. The anticorrelation between $\mathrm{Ni}$ concentration and $\delta^{60} \mathrm{Ni}$ could be explained by a binary mixing model. $\mathbf{b}$ Cross-plot of Ni concentration versus $\mathrm{Sm}_{\mathrm{N}} / \mathrm{Yb}_{\mathrm{N}}$. Here, Sm and $\mathrm{Yb}$ are used to represent middle rare earth element (MREE) and heavy REE (HREE) respectively. An anticorrelation is shown between $\mathrm{Ni}$ concentration and MREE/HREE. REE data are normalized to post-Archean Australian shale (PAAS). Green triangles, red circles, red squares, and red diamonds represent the Huakoushan, Tongle, Yazhai, and Datan sections, respectively.
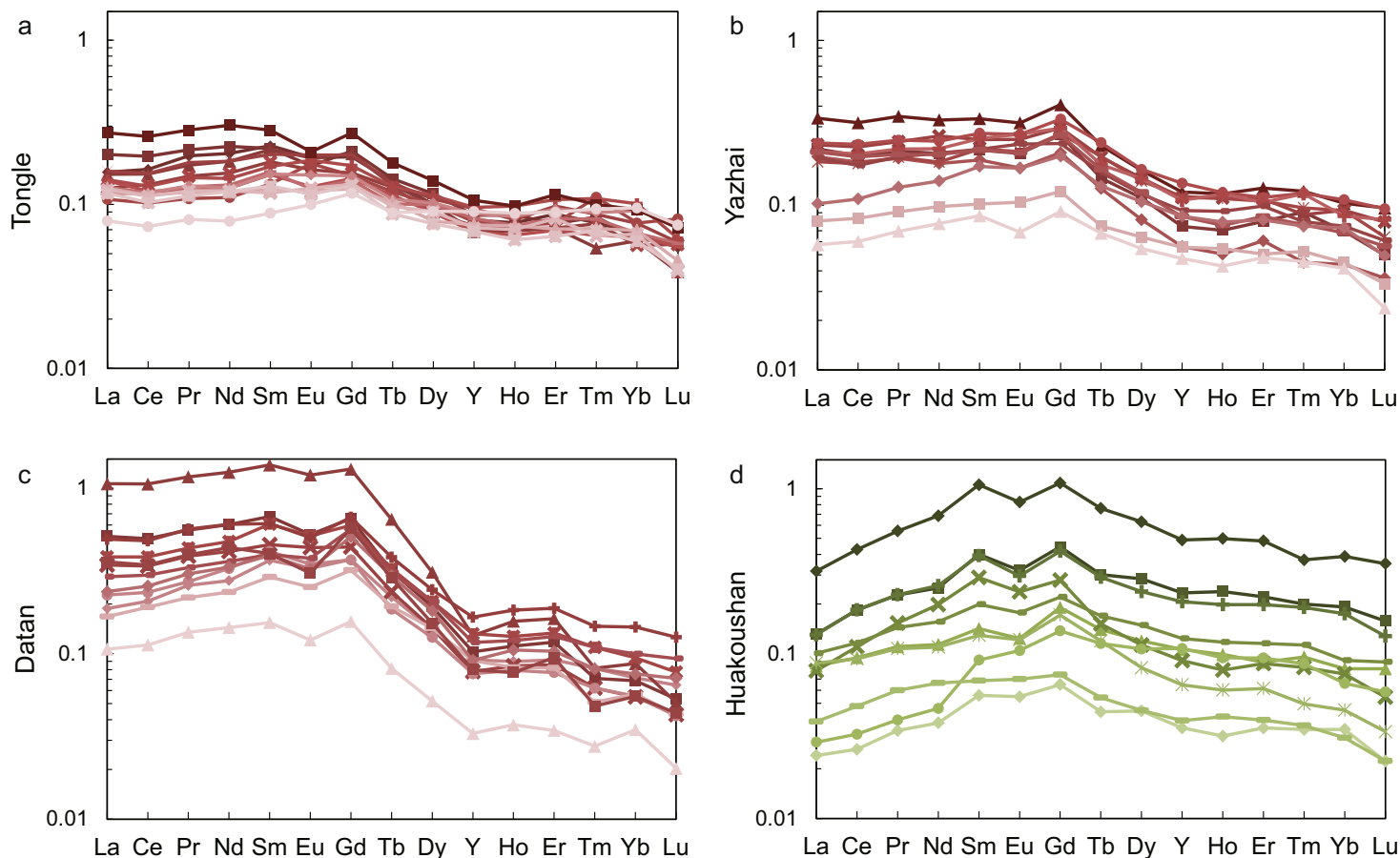

Fig. 4 Rare earth element pattern of the Nantuo pyrite. Rare earth element (REE) data are normalized to post-Archean Australian shale (PAAS). Samples formed in the basin environment (Tongle, Yazhai, and Datan section) are strongly depleted in HREE. Samples from the slope region (Huakoushan section) enrich in MREE.

(i.e., the Rayleigh distillation process) or MSR in bottom seawater with $\mathrm{H}_{2} \mathrm{~S}$ diffused into porewater. However, the former scenario could only contributes to pyrite content of $<0.1 \mathrm{wt} . \%$, which cannot explain abundant pyrite precipitation up to $10 \mathrm{wt} . \%$ (ref. ${ }^{7}$ ). As a result, MSR may have occurred in the bottom seawater, while the pyrite was formed during early diagenesis with $\mathrm{H}_{2} \mathrm{~S}$ diffusion from sulfidic seawater.

In this study, we focus on $\mathrm{Ni}$ isotopes. $\mathrm{Ni}$ is the core metal in the porphyrin ring of the coenzyme for methanogenesis ${ }^{22,23}$. Methanogens preferentially utilize isotopically light $\mathrm{Ni}$ with an isotopic fractionation up to $-0.8 \%$ o (ref. ${ }^{24}$ ). Other microbes also utilize $\mathrm{Ni}$, but there is no evidence showing that other microbes could fractionate $\mathrm{Ni}$ isotopes (Fig. $5 b)^{24}$. Terrestrial plants can fractionate $\mathrm{Ni}$ isotopes ${ }^{25}$, but it is reasonable to argue that $\mathrm{Ni}$ isotope fractionation in Proterozoic samples cannot be explained by the biological fractionation of land plants ${ }^{26}$. Thus, we infer that $\mathrm{Ni}$ isotopes can trace methanogenesis in Proterozoic.

It should be noted that interpretation of $\mathrm{Ni}$ isotopes might be complicated by other abiotic processes. Igneous rocks have nearly homogeneous $\mathrm{Ni}$ isotopic compositions with $\delta^{60} \mathrm{Ni} \approx+0.15 \%$ (Fig. 5a) ${ }^{27-31}$, while the average $\delta^{60} \mathrm{Ni}$ value for meteorites is around $+0.23 \%$ o (refs. ${ }^{32-34}$ ). Continental weathering fractionates $\mathrm{Ni}$ isotopes with heavy $\mathrm{Ni}$ being preferentially released into solution. As such, modern seawater has $\delta^{60} \mathrm{Ni}$ of $\sim+1.4 \%$ (refs. ${ }^{28,35}$ ). The $\delta^{60} \mathrm{Ni}$ values for euxinic Black Sea deep water could be up to $\sim+2.0 \%$ (ref. ${ }^{36}$ ), perhaps caused by the Mn 

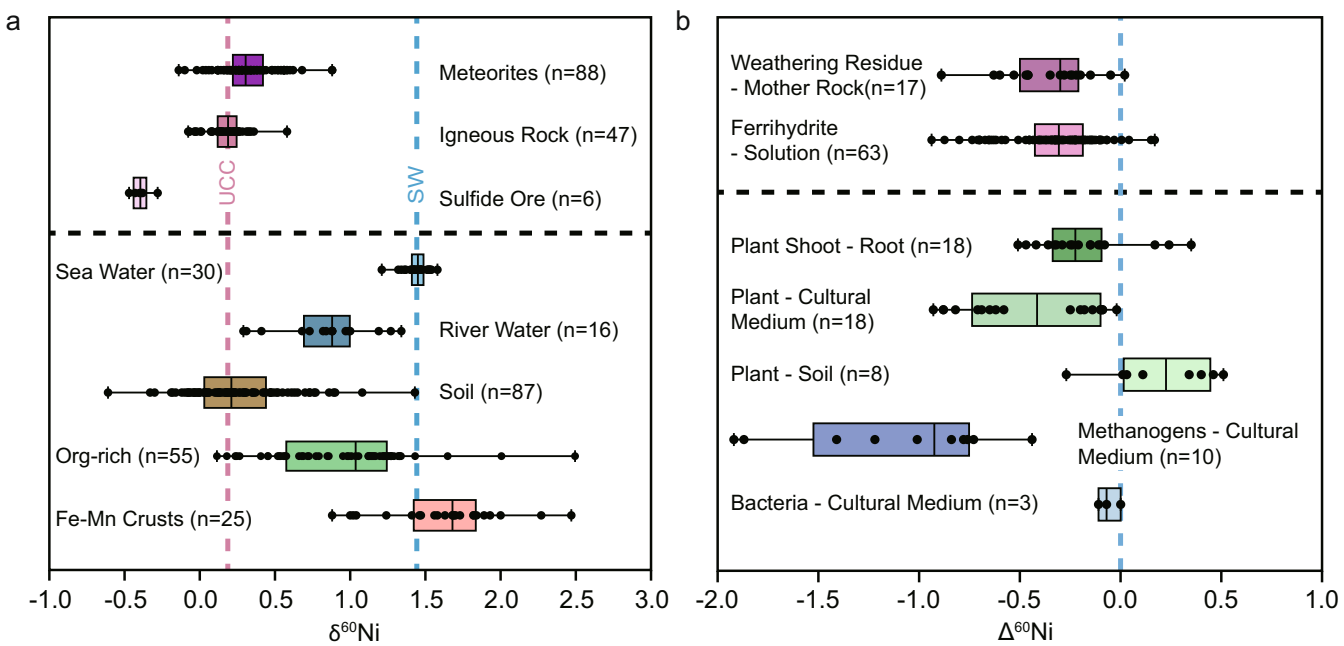

Fig. 5 Compilations of the $\mathbf{N i}$ isotopes data. a Boxplots showing the Ni isotopic compositions of different reservoirs $29-31,42,43,67-70$. The box showing the range for $\delta^{60} \mathrm{Ni}$ value between upper and lower quartiles. The vertical line inside the box represents the median value, while that outside the box represents the maximum and minimum value. The red and blue dash lines represent the upper continental crust (UCC) and modern seawater compositions, respectively 28,66 . b Boxplot showing the $\mathrm{Ni}$ isotopic fractionations in various geochemical processes 29,38 . The weathering process preferentially dissolves heavy $\mathrm{Ni}$, and laboratory experiment shows preferential absorption of light $\mathrm{Ni}$ in ferrihydrite precipitation ${ }^{41}$. Plants and methanogens preferentially absorb light $\mathrm{Ni}$ (ref. ${ }^{25}$ ).

recycling near the redoxcline. In addition, Fe-oxyhydroxide and sulfide precipitation preferentially absorb light $\mathrm{Ni}$ isotopes ${ }^{29,37-43}$, which would interfere with $\mathrm{Ni}$ isotopic fractionation by methanogenesis. These biological and abiotic processes can be further evaluated by the YREE system.

The REE pattern (normalized to shale) of igneous rocks show a LREE-depleted pattern (LREE $<$ MREE $\approx$ HREE; Fig. 6a) ${ }^{44}$, while the modern surface seawater is characterized by the HREEenriched distribution and a negative Ce anomaly (Fig. 6b) ${ }^{45}$. By contrast, REE of anoxic porewater displays either a flat (i.e., $\mathrm{LREE} \approx \mathrm{MREE} \approx \mathrm{HREE})$, HREE-enriched or MREE-enriched pattern (Fig. 6b) ${ }^{45}$. In the Black Sea, strong Ce negative anomaly can be seen in shallow water $(<100 \mathrm{~m})$, due to the active Mn redox cycle, but a relatively flat REE pattern can be seen in deep water (Fig. 6d) ${ }^{46}$. Precipitation of Fe-oxyhydroxides causes a negative yttrium anomaly and displays a flat or LREE $<$ MREE $\approx$ HREE pattern (Fig. 6h) ${ }^{47}$. Ancient Fe-oxide deposits (i.e., BIF) show positive $\mathrm{Eu}$ and $\mathrm{Y}$ anomalies, while modern ferrihydrite deposition shows a positive $\mathrm{Ce}$ anomaly and a negative $\mathrm{Y}$ anomaly (Fig. 6e) ${ }^{48,49}$. The REE patterns for hydrothermal fluid and hydrothermal sulfides are flat with a characteristic Eu positive anomaly, but the amplitude of Eu anomaly for sulfide is smaller than that of hydrothermal fluid (Fig. 6c) ${ }^{17-19}$. Hydrothermal fluids and hydrothermal precipitates in the mid-ocean ridges are strongly enriched in Eu (Fig. 6c) ${ }^{17,19}$. Pedestal slab near the chimney shows a MREE-depleted pattern and is enriched in both Eu and Y (Fig. $6 \mathrm{c})^{50}$. The similar REE pattern between hydrothermal fluid and hydrothermal pyrite implies that pyrite precipitation did not fractionate REE (Fig. 6i) ${ }^{18,19,51,52}$. A weak Eu enrichment and a slight HREE-enriched pattern in sulfide may be explained by mixing with low temperature seawater ${ }^{19}$. It is also reasonable to speculate that Yttrium would not be fractionated by sulfide precipitation since no Yttrium anomaly is found in peripheral chimney (Fig. 6c) ${ }^{50}$. Primordial plants, including moss, lichen, and algae, show a flat YREE pattern, except for green algae which depletes in Nd (Fig. 6f) 53,54 . Since microbes preferentially absorb HREE, organic matter produced by microbes (i.e., biomass of microbes) is characterized by LREE $\approx$ MREE $<$ HREE (Fig. 6g) ${ }^{55-57}$. Therefore, although both methanogenesis and Feoxyhydroxides precipitation preferentially utilize/scavenge light
$\mathrm{Ni}$ isotopes, methanogenesis can be distinguished by the HREE enrichment and the absence of Y anomaly.

The combination of $\mathrm{Ni}$ isotopes and YREE data can be used to trace methanogenesis during the Nantuo pyrite precipitation. Contamination of clay minerals could alter both $\mathrm{Ni}$ and REE concentrations. Only samples from the slope region (HKS section) show positive correlations between $\mathrm{Ni}$ concentration, MREE/HREE and Al, Ti contents (Fig. S4 in SI), suggesting the potential contamination from clays. For the same reason, absence of such correlations can rule out clay contamination in all basin samples (Fig. S5 in SI). Thus, both $\mathrm{Ni}$ and YREE in the basin samples appear to be derived from pyrite.

$\delta^{60} \mathrm{Ni}$ values of the Nantuo pyrites show a wide range of variation. There is a negative correlation between $\delta^{60} \mathrm{Ni}$ and $\mathrm{Ni}$ concentration (Fig. 3a). A similar negative correlation is observed between MREE/HREE ratio and Ni concentration (Fig. 3b). These anticorrelations could be explained in two ways: (1) the Rayleigh fractionation in a closed system during pyrite precipitation, and (2) a binary mixing between two end-members with different $\delta^{60} \mathrm{Ni}$ values and $\mathrm{Ni}$ concentrations.

In the first scenario, i.e., the Rayleigh process in a closed system, both light $\mathrm{Ni}$ isotopes and HREE should be preferentially removed from porewater, elevating $\delta^{60} \mathrm{Ni}$ value and depleting HREE in porewater. We suggest that pyrite precipitation cannot be the major process for removing porewater $\mathrm{Ni}$ in the Rayleigh distillation. Although light $\mathrm{Ni}$ would be preferentially removed, pyrite precipitation does not fractionate $\mathrm{REE}^{18,19,51,52}$. Alternatively, methanogens preferentially utilize both light $\mathrm{Ni}$ and HREE (Figs. $3 \mathrm{~b}$ and $6 \mathrm{~g}$ ) $24,55-57$, lowering the Ni concentration, and elevating $\delta^{60} \mathrm{Ni}$ and $\mathrm{Sm} / \mathrm{Yb}$ ratio of porewater. Therefore, pyrite precipitation in porewater with active methanogenesis would generate anticorrelations of $\mathrm{Ni}$ concentration, with both $\delta^{60} \mathrm{Ni}$ and $\mathrm{Sm} / \mathrm{Yb}$ ratio. However, we suggest that the Rayleigh distillation in a close porewater system is unlikely, because high pyrite content requires sufficient connection between porewater and seawater, allowing sustained diffusion of seawater $\mathrm{H}_{2} \mathrm{~S}$ (ref. ${ }^{7}$ ).

Alternatively, the anticorrelation could also be explained by the binary mixing of two sources (see text in SI) ${ }^{58,59}$. One endmember has a lower $\delta^{60} \mathrm{Ni}$ value and is enriched in HREE 

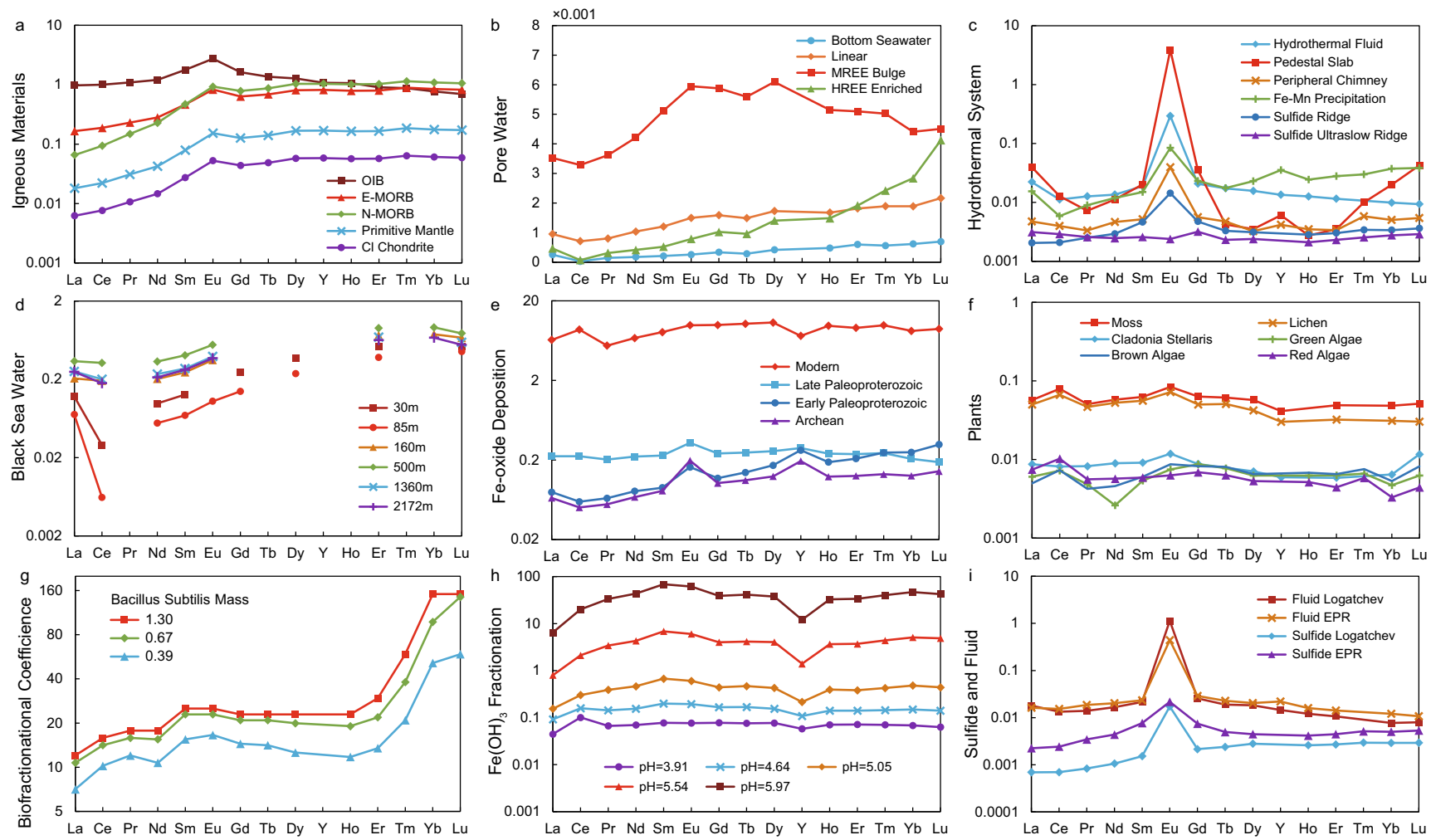

Fig. 6 Compilations of rare earth element pattern. All rare earth element (REE) data are normalized to post-Archean Australian shale (PAAS) ${ }^{44}$. a REE pattern of igneous rocks. All samples show Eu positive anomalies. All except for oceanic island basalt (OIB) show light REE (LREE)-depleted pattern; b REE pattern of porewater. REE pattern of the bottom water is similar to that of seawater. The middle REE (MREE) bulge type is found in Fe rich cores. The heavy REE (HREE)-enriched type is found in Fe lean cores. All samples slightly enrich in HREE ${ }^{45}$; c REE pattern of hydrothermal fluids and precipitates. Most samples show a flat REE pattern, except for the pedestal slab near chimney showing a MREE-depleted pattern ${ }^{17,19,50}$. All samples show a positive Eu anomaly except for sulfide from ultraslow spreading ridge. Pedestal slab and Fe-Mn precipitation show a slight $\mathrm{Y}$ enrichment ${ }^{50}$. d REE pattern for Black Seawater. Strong Ce negative anomaly could be characterized in shallow water. Deep water shows flat REE pattern with slight HREE enrichment ${ }^{46}$. e REE pattern of Fe-oxide deposition. Modern samples are ferrihydrite precipitation on seafloor, while samples from Paleoproterozoic and Archean era are banded-iron-formation (BIF). Modern samples show flat pattern with slight Ce positive anomaly and negative $Y$ anomaly. BIF samples show positive Eu and $\mathrm{Y}$ anomaly ${ }^{48}$. f REE pattern for modern primordial plants including lichen, algae, and moss. ${ }^{53,54}$ All samples show a flat REE pattern, except for green algae that is slightly depleted Nd (ref. ${ }^{54}$ ). $\mathbf{g}$ Fractional coefficient for microbes. Different lines show fractional coefficient for different biomass concentration. Microbes preferentially absorb HREE ${ }^{57}$. h REE fractionation during $\mathrm{Fe}(\mathrm{OH})_{3}$ precipitation. All data show LREE-depleted pattern with a slight $\mathrm{Y}$ negative anomaly. Smaller fractionation is observed in acidic environment ${ }^{47}$. i Comparison of REE pattern for fluid end-member and sulfide from Logatchev (midocean ridge in Atlantic Ocean) and east Pacific rise (EPR) ${ }^{19}$. The REE pattern for sulfide and fluid end-member is generally similar. A smaller positive Eu anomaly and slight HREE enrichment might be caused by contamination of seawater ${ }^{19}$.

(LREE $\approx$ MREE $<$ HREE), while the other is characterized by a higher $\delta^{60} \mathrm{Ni}$ value and a HREE-depleted pattern (LREE $\approx$ MREE $>$ HREE). Igneous rock fragment has a low $\delta^{60} \mathrm{Ni}$ value, but shows a LREE $<$ MREE $\approx$ HREE pattern (Fig. $6 a)^{44}$, and thus cannot be the low- $\delta^{60} \mathrm{Ni}$ end-member. The interference of $\mathrm{Mn}$ cycle can be ruled out because of the absence of $\mathrm{Ce}$ anomaly ${ }^{46}$. Primordial plants could not be the end-member either, since they show a flat REE pattern (Fig. 6f f3,54 $^{5}$. Contamination of Fe-oxyhydroxides could also be excluded by the absence of yttrium anomaly (Fig. 4). Another candidate of the low- $\delta^{60} \mathrm{Ni}$ end-member is the biomass of methanogens, i.e., organic matter produced by methanogens ${ }^{24}$. Because microbes preferentially absorb HREE and methanogens prefer light $\mathrm{Ni}$ isotope ${ }^{55-57}$, the biomass of methanogens would have a $\mathrm{LREE} \approx \mathrm{MREE}<\mathrm{HREE}$ pattern and a low $\delta^{60} \mathrm{Ni}$ value (Fig. 6g).

The heavy $\delta^{60} \mathrm{Ni}$ end-member with low $\mathrm{Ni}$ content might be represented by porewater or seawater that has been modified by methanogenesis. Wherever methanogenesis occurs, absorption of HREE and preferential utilization of light $\mathrm{Ni}$ by methanogens would result in a depletion of HREE and an enrichment of heavy
Ni (refs. ${ }^{55,56}$ ). During syndepositional pyrite precipitation in sediment porewater, degradation of methanogens would provide both light Ni and HREE. Various degree of biomass degradation during pyrite precipitation would generate a negative correlation between $\delta^{60} \mathrm{Ni}$ and $\mathrm{Ni}$ concentration, and between MREE/HREE and $\mathrm{Ni}$ concentration (Fig. 3).

$\mathrm{Ni}$ isotopes and YREE data of the Nantuo pyrites indicate degradation of organic matter that was derived from methanogenesis, and the release of light $\mathrm{Ni}$ and HREE, suggesting active methanogenesis during pyrite precipitation. Methanogenesis could occur in both porewater and seawater. However, syndepositional origin of the Nantuo pyrite requires active MIR in sediment porewater, which would outcompete methanogenesis ${ }^{7}$. In addition, the limited supply in methyl sulfide in the MIR zone would lower the efficiency of methanogenesis in sediment porewater. Thus, methanogenesis may not be a predominant microbial process in sediments.

Instead, we suggest that active methanogenesis might occur in sulfidic seawater. Theoretically, methanogenesis would be inhibited in the presence of sulfide ${ }^{60}$. However, the methanogenesis 


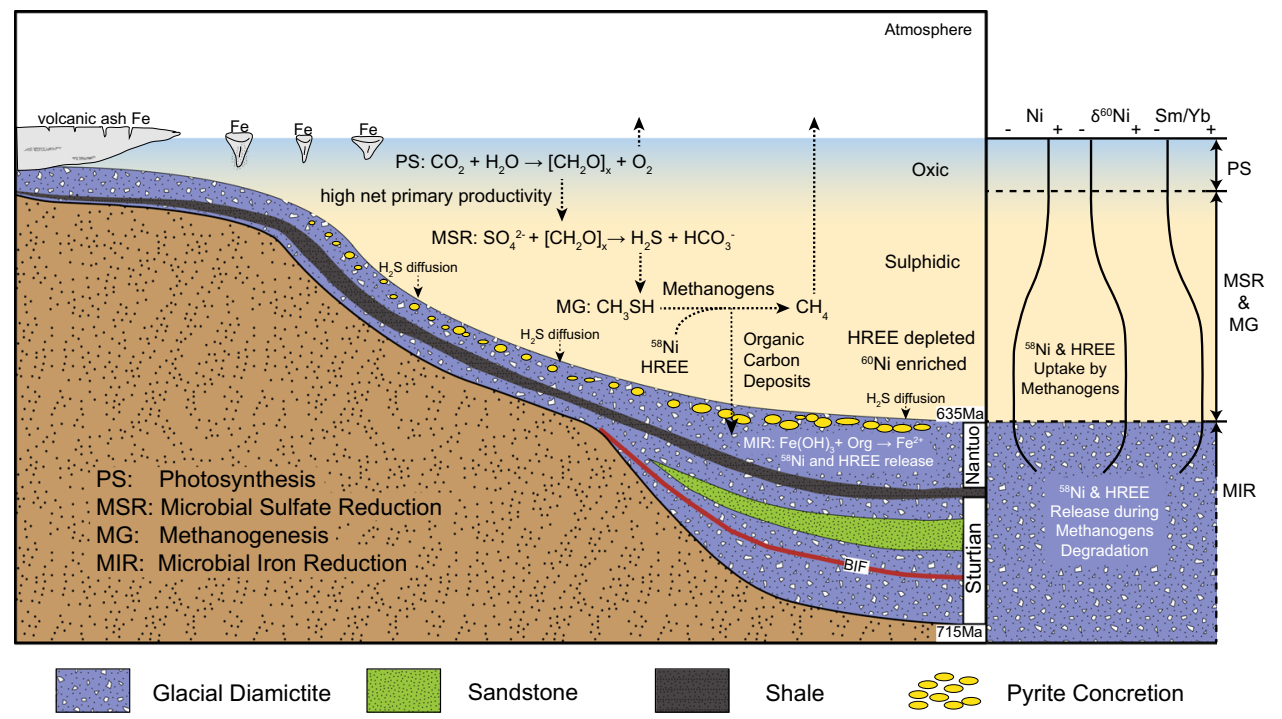

Fig. 7 Schematic model showing the biogeochemical cycles during the termination of Marinoan snowball Earth in the Yangtze Block. The recovery of primary productivity provided abundant organic matter in the euphotic zone by photosynthesis (PS), fueling microbial sulfate reduction (MSR) in the water column. Seawater MSR sustained sulfidic condition. ${ }^{7}$ Active methanogenesis (MG) might be fueled by methyl sulfide that was produced by $\mathrm{H}_{2} \mathrm{~S}-$ methylation in sulfidic seawater. Since methanogens preferentially absorb light $\mathrm{Ni}$ and heavy rare earth element (HREE), seawater was characterized by higher $\delta^{60} \mathrm{Ni}$ and displayed a HREE-depleted pattern. Sinking of particulate biomass of methanogens into sediments sustained microbial iron reduction (MIR), which converted ferric $\mathrm{Fe}\left(\mathrm{Fe}^{3+}\right)$ to $\mathrm{Fe}^{2+}$, and released absorbed light $\mathrm{Ni}$ and HREE in porewater. Syndepositional pyrite precipitation in sediment porewater would incorporate both seawater and porewater signals, and various degree of degradation of methanogen-derived organic matter led to a negative correlation between $\mathrm{Ni}$ concentration and $\delta^{60} \mathrm{Ni}$.

and MSR zones could converge with the presence of methyl sulfides, which can serve as a noncompetitive substrate for methanogens. Methyl sulfides, such as dimethyl sulfide $\left(\mathrm{CH}_{3} \mathrm{SCH}_{3}\right)$ and methanethiol $\left(\mathrm{CH}_{3} \mathrm{SH}\right)$, could be abundantly generated in sulfidic water via sulfide methylation ${ }^{61}$. It is highly plausible that active methanogenesis together with MSR occurred in the sulfidic water column during the deglacial recovery of primary productivity (Fig. 7).

In the deglacial sulfidic seawater with presumably ample supply of methyl sulfide via sulfide methylation, methanogens preferentially utilize light $\mathrm{Ni}$ isotopes and scavenge HREE, driving seawater enriched in heavy $\mathrm{Ni}$ isotopes and depleted of HREE. If methanogenesis-derived organic matter enriched in light $\mathrm{Ni}$, and HREE was delivered to the sediment and fueled MIR in sediment porewater, various degree of degradation would generate negative correlations between $\delta^{60} \mathrm{Ni}$ and $\mathrm{Ni}$ content, and between $\mathrm{Sm} / \mathrm{Yb}$ and $\mathrm{Ni}$ content (Fig. 3).

Active methanogenesis in sulfidic seawater also implies an unusual microbial metabolic loop during the deglaciation of Marinoan snowball Earth. In this scenario, high organic matter production would be induced by intense continental weathering, while decomposition of primarily produced organic matter depleted $\mathrm{O}_{2}$ in seawater and allowed active MSR in the water column, sustaining the sulfidic conditions ${ }^{7}$. Methyl sulfide formed in sulfidic seawater may function as a noncompetitive substrate for methanogens ${ }^{61-64}$. Active methanogenesis might also contribute to the organic matter production within sulfidic water column and sustain MIR in sediment porewater by providing additional organic substrate.

As such, during the deglacial recovery of primary productivity, photosynthesis took place in the euphotic zone, MSR and methanogenesis occurred in sulfidic water column, and MIR dominated in sediment porewater (Fig. 7). Such redox zonation is different from the canonical model with the MSR zone underlying the MIR zone, but overlying the methanogenesis zone in sediments ${ }^{60}$, and implies a critically different redox profile. More importantly, such microbial metabolic network might efficiently remineralize organic matter, lowering the $\delta^{13} \mathrm{C}$ values of seawater before cap carbonate precipitation.

Finally, it is also inferred from this study that active $\mathrm{CH}_{4}$ production occurred before cap carbonate precipitation. On one hand, most $\mathrm{CH}_{4}$ produced in seawater might be released into atmosphere, exacerbating the greenhouse condition during deglaciation. On the other hand, $\mathrm{CH}_{4}$ production near the seafloor or within sediments was likely to be stored as $\mathrm{CH}_{4}$ clathrate ${ }^{65}$. The following clathrate destabilization and $\mathrm{CH}_{4}$ oxidation would provide excessive ${ }^{12} \mathrm{C}$ at local or regional scale, leaving traces of methane-derived carbon isotope signal in cap carbonate ${ }^{13}$.

\section{Methods}

Sample preparation and digestion. Fresh outcrop samples were used for chemical composition analysis. In order to minimize the influence of weathering and silicate component, only samples with euhedral pyrite crystals were used. Pyrite aggregates were selected under stereoscope. Pyrite nodules were directly knocked down from the host rock. Selected pyrites were digested using the mixture of concentrated $\mathrm{HNO}_{3}$ and $\mathrm{HCl}$, until the liquid was clear and only a little insoluble silicate clast left. The liquid was evaporated to dry, then completely dissolved in the mixture of $1 \mathrm{~mol} / \mathrm{L} \mathrm{HCl}$ and $1 \mathrm{~mol} / \mathrm{L} \mathrm{HNO}_{3}$. After centrifugated, the supernatant was used for further analysis. Samples digestion was conducted at the Isotope Geochemistry Laboratory of China University of Geosciences, Beijing.

Major and trace elements analyses. Concentrations of major and trace elements were measured by ICP-OES (Spectro Blue Sop) at Peking University. REE concentrations were measured by inductively coupled plasma mass spectrometer (ICPMS; Perkin Elmer NexION300) in Chinese Academy of Geological Sciences. Element concentration for the pyrite was calculated based on whole rock mass. The reproducibility for major and minor elements (including $\mathrm{Fe}, \mathrm{Ni}$, and $\mathrm{REE}$ ) is better than $5 \%$.

Nickel isotope analysis. Samples containing $\sim 200 \mathrm{ng} \mathrm{Ni}$ was used for Ni purification and isotope analysis. Before $\mathrm{Ni}$ purification, ${ }^{61} \mathrm{Ni}-{ }^{62} \mathrm{Ni}$ double spike was mixed with the sample solution. The optimized ratio of ${ }^{62} \mathrm{Ni}_{\text {spike }} \cdot{ }^{58} \mathrm{Ni}_{\text {sample }}$ is $\sim 1.3$ Five purification procedures were used to suppress the interference from $\mathrm{Fe}, \mathrm{Zn}$, $\mathrm{Mg}, \mathrm{Ca}$, and other elements (see SI) ${ }^{66}$. The yield of $\mathrm{Ni}$ for the total procedure is $>90 \%$. The procedure blank for ${ }^{60} \mathrm{Ni}$ is negligible relative to sample signal $(1-2 \mathrm{~V})$ Four geological standard materials (BHVO-2, BCR-2, NOD-A-1, and NOD-P-1) were processed with sample for chemical purification. The purified Ni solution 
with $\mathrm{Fe} / \mathrm{Ni}, \mathrm{Zn} / \mathrm{Ni}, \mathrm{Ca} / \mathrm{Ni}$, and $\mathrm{Mg} / \mathrm{Ni}<0.01$ was analyzed on a $\mathrm{Nu}$ plasma II High Resolution Multi-Collector ICP-MS at State Key Laboratory of Environmental Geochemistry in Institute of Geochemistry, Chinese Academy of Sciences, Guiyang. Faraday cups L5, L4, L2, AX, H2, H4, H6, H7, and H8 are used to collect ${ }^{57} \mathrm{Fe},{ }^{58}(\mathrm{Fe}, \mathrm{Ni}),{ }^{59} \mathrm{Co},{ }^{60} \mathrm{Ni},{ }^{61} \mathrm{Ni},{ }^{62} \mathrm{Ni},{ }^{63} \mathrm{Cu},{ }^{64}(\mathrm{Ni}, \mathrm{Zn}),{ }^{65} \mathrm{Cu}$, and ${ }^{66} \mathrm{Zn}$, respectively. The isobaric interference from ${ }^{58} \mathrm{Fe}$ and ${ }^{64} \mathrm{Zn}$ were corrected by ${ }^{57} \mathrm{Fe}$ and ${ }^{66} \mathrm{Zn}$, respectively. ${ }^{58} \mathrm{Ni},{ }^{60} \mathrm{Ni},{ }^{61} \mathrm{Ni}$, and ${ }^{62} \mathrm{Ni}$ are used for analysis here. $\mathrm{Ni}$ isotopic values are reported by $\delta$-notation as \% deviation relative to NIST 986 standard: $\delta^{x} \mathrm{Ni}=\left[\left({ }^{x} \mathrm{Ni} /{ }^{58} \mathrm{Ni}\right)_{\text {sample }} /\left({ }^{x} \mathrm{Ni} /{ }^{58} \mathrm{Ni}\right)_{\text {NIST SRM } 986}-1\right] \times 1000$, where $x$ refers to 60 , 61 , or 62. Each measurement contains three blocks, each block contains ten cycles. The integration time for each cycle is $10 \mathrm{~s}$. The external precision of long-term measurement is $0.09 \%$ based on the multiple determination of reference materials. All measured values for the geological referencce materials are consistent with the published value (Fig. S6 in SI).

\section{Data availability}

All data in this study are available from the corresponding author via email upon reasonable request.

Received: 29 November 2019; Accepted: 8 January 2021;

Published online: 11 February 2021

\section{References}

1. Hoffman, P. F., Kaufman, A. J., Halverson, G. P. \& Schrag, D. P. A neoproterozoic snowball Earth. Nature 281, 1342-1346 (1998).

2. Sahoo, S. K. et al. Ocean oxygenation in the wake of the Marinoan glaciation. Nature 489, 546-549 (2012).

3. Yin, L. et al. Doushantuo embryos preserved inside diapause egg cysts. Nature 446, 661-663 (2007)

4. Zhou, C., Xie, G., McFadden, K., Xiao, S. \& Yuan, X. The diversification and extinction of Doushantuo-Pertatataka acritarchs in South China: causes and biostratigraphic significance. Geol. J. 42, 229-262 (2007).

5. Huang, K.-J. et al. Episode of intense chemical weathering during the termination of the $635 \mathrm{Ma}$ Marinoan glaciation. Proc. Natl Acad. Sci. USA 113 14904-14909 (2016).

6. Lang, X. et al. Ocean oxidation during the deposition of basal Ediacaran Doushantuo cap carbonates in the Yangtze Platform, South China. Precambrian Res. 281, 253-268 (2016).

7. Lang, X. et al. Transient marine euxinia at the end of the terminal Cryogenian glaciation. Nat. Commun. 9, 3019 (2018).

8. Hyde, W. T., Crowley, T. J., Baum, S. K. \& Peltier, W. R. Neoproterozoic 'snowball Earth' simulations with a coupled climate/ice-sheet model. Nature 405, 425-429 (2000)

9. Huang, K.-J. et al. Magnesium isotopic compositions of the Mesoproterozoic dolostones: Implications for $\mathrm{Mg}$ isotopic systematics of marine carbonates. Geochim. Cosmochim. Acta 164, 333-351 (2015).

10. Johnson, B. W., Poulton, S. W. \& Goldblatt, C. Marine oxygen production and open water supported an active nitrogen cycle during the Marinoan Snowball Earth. Nat. Commun. 8, 1316 (2017).

11. Kennedy, M. J., Christie-Blick, N. \& Sohl, L. E. Are Proterozoic cap carbonates and isotopic excursions a record of gas hydrate destabilization following Earth's coldest intervals? Geology 29, 443-446 (2001).

12. Wang, J., Jiang, G., Xiao, S., Li, Q. \& Wei, Q. Carbon isotope evidence for widespread methane seeps in the ca. 635 Ma Doushantuo cap carbonate in south China. Geology 36, 347 (2008).

13. Jiang, G., Kennedy, M. J. \& Christie-Blick, N. Stable isotopic evidence for methane seeps in Neoproterozoic postglacial cap carbonates. Nature $\mathbf{4 2 6}$ 822-826 (2003).

14. Condon, $\mathrm{D}$. et al. U-Pb ages from the Neoproterozoic Doushantuo formation, China. Scinece 308, 95-98 (2005).

15. Zhou, C., Huyskens, M. H., Lang, X., Xiao, S. \& Yin, Q.-Z. Calibrating the terminations of Cryogenian global glaciations. Geology 47, 251-254 (2019).

16. Lang, X. et al. Cyclic cold climate during the Nantuo Glaciation: evidence from the Cryogenian Nantuo Formation in the Yangtze Block, South China. Precambrian Res. 310, 243-255 (2018).

17. Douville, E. et al. Yttrium and rare earth elements in fluids from various deepsea hydrothermal systems. Geochim. Cosmochim. Acta 63, 627-643 (1999).

18. Mills, R. A. \& Elderfield, H. Rare earth element geochemistry of hydrothermal deposits from the active TAG Mound, $26^{\circ} \mathrm{N}$ Mid-Atlantic Ridge. Geochim. Cosmochim. Acta 59, 3511-3524 (1995).

19. Zeng, Z. et al. Factors affecting the rare earth element compositions in massive sulfides from deep-sea hydrothermal systems. Geochem. Geophys. Geosyst. 16, 2679-2693 (2015).
20. Lenstra, W. K. et al. Controls on the shuttling of manganese over the northwestern Black Sea shelf and its fate in the euxinic deep basin. Geochim. Cosmochim. Acta 273, 177-204 (2020).

21. Xiong, Y. et al. Phosphorus cycling in Lake Cadagno, Switzerland: a low sulfate euxinic ocean analogue. Geochim. Cosmochim. Acta 251, 116-135 (2019).

22. Scheller, S., Goenrich, M., Boecher, R., Thauer, R. K. \& Jaun, B. The key nickel enzyme of methanogenesis catalyses the anaerobic oxidation of methane. Nature 465, 606-608 (2010).

23. Konhauser, K. O. et al. Oceanic nickel depletion and a methanogen famine before the Great Oxidation Event. Nature 458, 750-753 (2009).

24. Cameron, V., Vance, D., Archer, C. \& House, C. H. A biomarker based on the stable isotopes of nickel. Proc. Natl Acad. Sci. USA 106, 10944-10948 (2009)

25. Deng, T. H. et al. Nickel and zinc isotope fractionation in hyperaccumulating and nonaccumulating plants. Environ. Sci. Technol. 48, 11926-11933 (2014).

26. Xue, J. et al. Belowground rhizomes in paleosols: the hidden half of an Early Devonian vascular plant. Proc. Natl Acad. Sci. USA 113, 9451-9456 (2016).

27. Gall, L., Williams, H., Siebert, C. \& Halliday, A. Determination of massdependent variations in nickel isotope compositions using double spiking and MC-ICPMS. J. Anal. At. Spectrom. 27, 137-145 (2012).

28. Cameron, V. \& Vance, D. Heavy nickel isotope compositions in rivers and the oceans. Geochim. Cosmochim. Acta 128, 195-211 (2014)

29. Elliott, T. \& Steele, R. C. J. The isotope geochemistry of Ni. Rev. Mineral. Geochem. 82, 511-542 (2017)

30. Gall, L., Williams, H. M., Halliday, A. N. \& Kerr, A. C. Nickel isotopic composition of the mantle. Geochim. Cosmochim. Acta 199, 196-209 (2017)

31. Gueguen, B., Rouxel, O., Ponzevera, E., Bekker, A. \& Fouquet, Y. Nickel isotope variations in terrestrial silicate rocks and geological reference materials measured by MC-ICP-MS. Geostand. Geoanal. Res. 37, 297-317 (2013).

32. Wang, H.-J. et al. Nickel isotopic evidence for late-stage accretion of Mercurylike differentiated planetary embryos. Nat. Commun. 12 (2021).

33. Moynier, F., Blichert-Toft, J., Telouk, P., Luck, J.-M. \& Albarède, F. Comparative stable isotope geochemistry of $\mathrm{Ni}, \mathrm{Cu}, \mathrm{Zn}$, and $\mathrm{Fe}$ in chondrites and iron meteorites. Geochim. Cosmochim. Acta. 71, 4365-4379 (2007).

34. Cook, D. L., Clayton, R. N., Wadhwa, M., Janney, P. E. \& Davis, A. M. Nickel isotopic anomalies in troilite from iron meteorites. Geophy. Res. Lett. 35 (2008).

35. Ratié, G. et al. Nickel isotope fractionation during tropical weathering of ultramafic rocks. Chem. Geol. 402, 68-76 (2015).

36. Vance, D. et al. The oceanic budgets of nickel and zinc isotopes: the importance of sulfidic environments as illustrated by the Black Sea. Philos. Trans. R. Soc. A Math. Phys. Eng. Sci. 374, 20150294 (2016).

37. Wasylenki, L. E., Howe, H. D., Spivak-Birndorf, L. J. \& Bish, D. L. Ni isotope fractionation during sorption to ferrihydrite: Implications for $\mathrm{Ni}$ in banded iron formations. Chem. Geol. 400, 56-64 (2015).

38. Wang, S.-J. \& Wasylenki, L. E. Experimental constraints on reconstruction of Archean seawater Ni isotopic composition from banded iron formations. Geochim. Cosmochim. Acta 206, 137-150 (2017).

39. Watkins, J. M., DePaolo, D. J. \& Watson, E. B. Kinetic Fractionation of nontraditional stable isotopes by diffusion and crystal growth reactions. Rev. Mineral. Geochem. 82, 85-125 (2017).

40. Hofmann, A. et al. Comparing orthomagmatic and hydrothermal mineralization models for komatiite-hosted nickel deposits in Zimbabwe using multiple-sulfur, iron, and nickel isotope data. Mineralium Depos. 49 75-100 (2013).

41. Gueguen, B. et al. Variable Ni isotope fractionation between Fe-oxyhydroxides and implications for the use of $\mathrm{Ni}$ isotopes as geochemical tracers. Chem. Geol. 481, 38-52 (2018)

42. Gall, L. et al. Nickel isotopic compositions of ferromanganese crusts and the constancy of deep ocean inputs and continental weathering effects over the Cenozoic. Earth Planet. Sci. Lett. 375, 148-155 (2013).

43. Gueguen, B. et al. Comparative geochemistry of four ferromanganese crusts from the Pacific Ocean and significance for the use of $\mathrm{Ni}$ isotopes as paleoceanographic tracers. Geochim. Cosmochim. Acta 189, 214-235 (2016).

44. Sun, S. S. \& McDonough, W. F. Chemical and isotopic systematics of oceanic basalts: implications for mantle composition and processes. Geol. Soc. Lond. Spec. Publ. 42, 313-345 (1989).

45. Haley, B. A., Klinkhammer, G. P. \& McManus, J. Rare earth elements in pore waters of marine sediments. Geochim. Cosmoch. Acta 68, 1265-1279 (2004).

46. Schijf, J., de Baar, H. J. W., Wijbrans, J. R. \& Landing, W. M. Dissolved rare earth elements in the Black Sea. Deep Sea Res. Part A Oceanograph. Res. Pap. 38, S805-S823 (1991).

47. Bau, M. Scavenging of dissolved yttrium and rare earths by precipitating iron oxyhydroxide: experimental evidence for Ce oxidation, Y-Ho fractionation, and lanthanide tetrad effect. Geochim. Cosmochim. Acta 63, 67-77 (1999).

48. Planavsky, N. et al. Rare Earth Element and yttrium compositions of Archean and Paleoproterozoic Fe formations revisited: new perspectives on the 
significance and mechanisms of deposition. Geochim. Cosmochim Acta 74, 6387-6405 (2010).

49. Alibert, C. Rare earth elements in Hamersley BIF minerals. Geochim. Cosmochim Acta 184, 311-328 (2016).

50. Paropkari, A. L. et al. Formation of hydrothermal deposits at Kings Triple Junction, northern Lau back-arc basin, SW Pacific: the geochemical perspectives. J. Asian Earth Sci. 38, 121-130 (2010).

51. Haas, J. R., Shock, E. L. \& Sassani, D. C. Rare earth elements in hydrothermal systems: estimates of standard partial molal thermodynamic properties of aqueous complexes of the rare earth elements at high pressures and temperatures. Geochim. Cosmochim. Acta 59, 4329-4350 (1995).

52. Cole, C. S., James, R. H., Connelly, D. P. \& Hathorne, E. C. Rare earth elements as indicators of hydrothermal processes within the East Scotia subduction zone system. Geochim. Cosmochim. Acta 140, 20-38 (2014).

53. Chiarenzelli, J. et al. Multi-element and rare earth element composition of lichens, mosses, and vascular plants from the Central Barrenlands, Nunavut, Canada. Appl. Geochem. 16, 245-270 (2001).

54. Rusu, A.-M., Chimonides, P. D. J., Jones, G. C., Garcia-Sanchez, R. \& Purvis, O. W. Multi-element including rare Earth content of lichens, bark, soils, and waste following industrial closure. Environ. Sci. Technol. 40, 4599-4604 (2006).

55. Takahashi, Y., Châtellier, X., Hattori, K. H., Kato, K. \& Fortin, D. Adsorption of rare earth elements onto bacterial cell walls and its implication for REE sorption onto natural microbial mats. Chem. Geol. 219, 53-67 (2005).

56. Takahashi, Y., Hirata, T., Shimizu, H., Ozaki, T. \& Fortin, D. A rare earth element signature of bacteria in natural waters? Chem. Geol. 244, 569-583 (2007).

57. Martinez, R. E., Pourret, O. \& Takahashi, Y. Modeling of rare earth element sorption to the Gram positive Bacillus subtilis bacteria surface. J. Colloid Interface Sci. 413, 106-111 (2014).

58. Li, F.-B. et al. Constraining ribbon rock dolomitization by $\mathrm{Mg}$ isotopes: Implications for the 'dolomite problem'. Chem. Geol. 445, 208-220 (2016).

59. Peng, Y. et al. Constraining dolomitization by Mg isotopes: a case study from partially dolomitized limestones of the middle Cambrian Xuzhuang Formation, North China. Geochem. Geophys. Geosyst. 17, 1109-1129 (2016).

60. Canfield, D. E. \& Thamdrup, B. Towards a consistent classification scheme for geochemical environments, or, why we wish the term 'suboxic' would go away. Geobiology 7, 385-392 (2009).

61. Oduro, H., Kamyshny, A., Guo, W. \& Farquhar, J. Multiple sulfur isotope analysis of volatile organic sulfur compounds and their sulfonium precursors in coastal marine environments. Mar. Chem. 124, 78-89 (2011).

62. Oduro, H., Kamyshny, A., Zerkle, A. L., Li, Y. \& Farquhar, J. Quadruple sulfur isotope constraints on the origin and cycling of volatile organic sulfur compounds in a stratified sulfidic lake. Geochim. Cosmochim. Acta $\mathbf{1 2 0}$ 251-262 (2013).

63. Wang, S.-J., Rudnick, R. L., Gaschnig, R. M., Wang, H. \& Wasylenki, L. E. Methanogenesis sustained by sulfide weathering during the Great Oxidation Event. Nat. Geosci. 12, 296-300 (2019).

64. Shen, B. et al. Molar tooth carbonates and benthic methane fluxes in Proterozoic oceans. Nat. Commun. 7, 10317 (2016).

65. Lamarche-Gagnon, G. et al. Greenland melt drives continuous export of methane from the ice-sheet bed. Nature 565, 73-77 (2019).

66. Wu, G. et al. A novel purification method for high precision measurement of $\mathrm{Ni}$ isotopes by double spike MC-ICP-MS. J. Anal. At. Spectrom. 34, 1639-1651 (2019).

67. Spivak-Birndorf, L. J., Wang, S.-J., Bish, D. L. \& Wasylenki, L. E. Nickel isotope fractionation during continental weathering. Chem. Geol. 476 316-326 (2018).
68. Ratié, G. et al. Nickel distribution and isotopic fractionation in a Brazilian lateritic regolith: coupling $\mathrm{Ni}$ isotopes and Ni K-edge XANES. Geochim. Cosmochim. Acta 230, 137-154 (2018).

69. Ciscato, E. R., Bontognali, T. R. R. \& Vance, D. Nickel and its isotopes in organic-rich sediments: implications for oceanic budgets and a potential record of ancient seawater. Earth Planet. Sci. Lett. 494, 239-250 (2018).

70. Porter, S. J., Selby, D. \& Cameron, V. Characterising the nickel isotopic composition of organic-rich marine sediments. Chem. Geol. 387, 12-21 (2014).

\section{Acknowledgements}

We gratefully acknowledge Yuchen Wang and Wenbo Tang for proofreading. This work was supported by the National Natural Science Foundation of China (grant numbers 41772359 to B.S., U1612441 to J.-M.Z., and 41802024 to X.L.).

\section{Author contributions}

B.S. and J.-M.Z. designed the work, B.S., X.L., and H.M. conducted field work. Z.Z., J.-M.Z., G.W., D.T., H.P., T.H., M.N., and H.M. analyzed data. Z.Z. and B.S. led data interpretation. Z.Z., B.S., J.-M.Z., X.L., and G.W. developed the manuscript. All author contributed to the discussion and revision of the manuscript.

\section{Competing interests}

The authors declare no competing interests.

\section{Additional information}

Supplementary information The online version contains supplementary material available at https://doi.org/10.1038/s41467-021-21114-6.

Correspondence and requests for materials should be addressed to B.S., J.-M.Z. or X.L

Peer review information Nature Communications thanks Bleuenn Gueguen, Ganqing Jiang and other, anonymous, reviewers for their contributions to the peer review of this work. Peer review reports are available.

Reprints and permission information is available at http://www.nature.com/reprints

Publisher's note Springer Nature remains neutral with regard to jurisdictional claims in published maps and institutional affiliations.

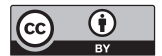

Open Access This article is licensed under a Creative Commons Attribution 4.0 International License, which permits use, sharing, adaptation, distribution and reproduction in any medium or format, as long as you give appropriate credit to the original author(s) and the source, provide a link to the Creative Commons license, and indicate if changes were made. The images or other third party material in this article are included in the article's Creative Commons license, unless indicated otherwise in a credit line to the material. If material is not included in the article's Creative Commons license and your intended use is not permitted by statutory regulation or exceeds the permitted use, you will need to obtain permission directly from the copyright holder. To view a copy of this license, visit http://creativecommons.org/ licenses/by/4.0/.

(C) The Author(s) 2021 